https://doi.org/10.19195/0524-4544.330.2

\title{
MATEUSZ SZYMURA
}

ORCID: 0000-0001-7146-8477

Uniwersytet Wrocławski

mateusz.szymura@uwr.edu.pl

\section{Kilka uwag o genezie i roli Sądu Sesji w Królestwie Szkocji (1532-1707)}

James Alexander Lovat-Fraser, czyniąc spostrzeżenia o zakresie różnic i podobieństw między systemami prawnymi Szkocji i Anglii w okresie poprzedzającym unię personalną, do podobieństw - a może precyzyjniej do sfer, w których rozwiązania szkockie można uznać za inspirowane angielskimi — zalicza pojawienie się w pierwszej połowie XVI wieku w instytucji Sądu Sesji sądu centralnego Królestwa Szkocji ${ }^{1}$. Chociaż jest to spostrzeżenie trafne z punktu widzenia anglosaskiej percepcji rozwoju prawa szkockiego ${ }^{2}$, to jednak nie uwzględnia perspektywy ewolucji szkockiego systemu sądownictwa, stanowiącej odpowiedź na trapiące go problemy i potrzeby. Celem niniejszego opracowania jest próba ukazania funkcjonowania oraz najważniejszych kierunków rozwoju szkockiego Sądu Sesji od jego powstania w 1532 do 1707 roku $^{3}$, w którym to Sąd Sesji, na skutek

1 J.A. Lovat-Fraser, Differences between English and Scots law, „Law Quaterly Review” 10, 1894, s. 342.

2 Niewątpliwie utworzenie angielskich sądów centralnych w postaci sądów westminsterskich (Queen's Bench oraz Common Pleas) poprzedza wprowadzenie podobnych rozwiązań w prawie szkockim. Nie można jednak zapominać, że istniały również stare sądy w krajach, z którymi łączyły Szkocję szczególne stosunki polityczne - chodzi tutaj o kościelny trybunał Roty Rzymskiej oraz paryski Parlament, które funkcjonowały jako sądy centralne odpowiednio od XII i XIII wieku. Spór o genezę wzorca Sądu Sesji w postaci Kolegium Sprawiedliwości (College of Justice) toczy się w szkockiej nauce historii prawa od dłuższego czasu — R.K. Hannay (The College of Justice, Edinburgh 1991, s. 22-24) wskazuje na inspirowanie się funkcjonującym w Padwie Collegio dei Giudici, z czym nie zgadza się J.W. Cairns (Revisiting the Foundation of the College of Justice, [w:] Miscellany V, red. H.L. MacQueen, Edinburgh 2006, s. 27-50), który opowiada się za utrwalonym poglądem (wyrażanym między innymi przez Davida Hume'a) o inspiracji strukturą oraz zakresem kognicji paryskiego Parlamentu.

3 Wskazana cezura czasowa to okres niemalże nieprzerwanego funkcjonowania Sądu w omawianej formie. Poza zakresem opracowania pozostanie okres rewolucji angielskiej, który przyniósł 
traktatu zjednoczeniowego, stał się elementem struktury systemu sprawiedliwości Zjednoczonego Królestwa, co stanowiło przyczynek do kwestionowania ostateczności jego jurysdykcji ${ }^{4}$.

Pierwsze pewne informacje o sądownictwie cywilnym w Szkocji pochodzą z okresu panowania Roberta I Bruce’a (1306-1329), choć wskazuje się również na tworzenie pierwszych sądów szeryfów już od połowy XII wieku jako symbol scalania ram terytorialnych i instytucjonalnych młodego szkockiego królestwa ${ }^{5}$. Całość jurysdykcji w królestwie spoczywała w rękach panującego, działający zaś lokalnie szeryfowie występowali jako reprezentanci władzy królewskiej, a od ich wyroków strona niezadowolona mogła się odwołać do króla ${ }^{6}$. To właśnie w królewskiej jurysdykcji apelacyjnej, której wykonywanie z czasem musiało wymagać stworzenia odpowiedniego zaplecza administracyjnego oraz merytorycznego, należy doszukiwać się korzeni uprawnień jurysdykcyjnych Sądu Sesji.

Stosunkowo rzadkie przypadki odwołań od wyroków sądów szeryfów w XIV wieku umożliwiały korzystanie z mechanizmu osobistego wysłuchiwania skarg stron przez panującego ${ }^{7}$. W XV wieku doszło jednak do wzrostu liczby skarg na wyroki sądów niższej instancji, których składy częstokroć pozbawione były wykształconych jurystów. Początkowo król rozpoznawał sprawy przy pomocy swojej Rady Królewskiej ${ }^{8}$, jednak wzrost wpływu nowych spraw wymusił za panowania Jakuba I w 1425 roku powstanie centralnego sądu, który początkowo funkcjonował na zasadach specjalnej komisji parlamentarnej.

Zgodnie $\mathrm{z}$ ustawą przyjętą $\mathrm{w}$ trakcie parlamentu obradującego w Perth między 11 a 13 marca 1425 roku król zarządził specjalne posiedzenia przedstawicieli trzech stanów królestwa - szlachty, duchowieństwa i mieszczan. Komisja w tym składzie miała zbierać się co kwartał w celu rozpoznawania skarg w imieniu rady królewskiej9.

zawieszenie funkcjonowania Sądu w latach 1652-1660 i zastąpienie go Komisją dla Administracji Sprawiedliwości, której członkowie zostali mianowali przez angielskiego Lorda Protektora, Oliviera Cromwella.

${ }^{4}$ Zasygnalizowany problem związany jest z powstaniem jurysdykcji apelacyjnej brytyjskiej Izby Lordów nad orzeczeniami Sądu Sesji. Przedmiotowy problem autor niniejszego opracowania przedstawia w tekście Geneza jurysdykcji apelacyjnej Izby Lordów nad rozstrzygnięciami sądów szkockich, „Przegląd Prawa i Administracji” 120, 2020.

5 A.M. Godfrey, Civil Justice in Renaissance Scotland: The Origins of a Central Court, Boston 2009, s. 2.

6 J.C. Lorimer, History of the Court of Session, „Journal of Jurisprudence” 16, 1872, nr 185, s. 240 .

7 Więcej o jurysdykcji króla obradującego w obecności jego rady zob. J. Erskine, The Principles of the Law of Scotland, wyd. 6, Edinburgh 1783, 1.3.5., s. 23.

8 Nie było to jednak rozwiązanie oryginalne, albowiem geneza większości europejskich sądów centralnych wywodzi się z instytucji rady królewskiej (curia regis), która pomagała królowi w sprawowaniu władzy, a z czasem zaczęła się dzielić na mniejsze, wyspecjalizowane organy. Więcej zob. B. Guenée, States and Rulers in Later Medieval Europe, Oxford 1985, s. 5.

9 Ustawa $\mathrm{nr} 65 \mathrm{z} 1425$ roku. Zob. The Records of the Parliaments of Scotland to 1707, red. K.M. Brown, St Andrews 2007-2020, http://www.rps.ac.uk/trans/1426/25 (dostęp: 28 kwietnia 2020). 
Sąd, działając jako komisja parlamentarna ${ }^{10}$, podlegał dalszej ewolucji — do najważniejszych zmian należały: zakaz odwołań od decyzji tej komisji do pełnego składu parlamentu ${ }^{11}$, ograniczenie trwania urzędu sędziego-parlamentarzysty do czterdziestu dni sądowych (sesji) ${ }^{12}$ oraz ograniczenie składu komisji jedynie do przedstawicieli szlachty i duchowieństwa ${ }^{13}$. Bardzo istotnym rozwiązaniem było rozszerzenie zakazu odwoływania się od wyroków sądu parlamentarnego zapadłych w trakcie sesji do króla, co było pierwszym krokiem do wyjęcia najwyższej jurysdykcji sądowej z ram prerogatywy królewskiej na rzecz odrębnego organu. W tym okresie wprowadzono również zasadę odpowiedzialności finansowej strony przegrywającej spór oraz utrwalono model postępowania oparty na ustnym prezentowaniu stanowisk przed składem sędziowskim, bez udziału ławy przysięgłych ${ }^{14}$.

Rozwiązania te wyraźnie wskazują, że przed ukonstytuowaniem się Sądu Sesji jako odrębnego organu istniały próby utworzenia organu odpowiadającego za najwyższą jurysdykcję cywilną na podstawie istniejących struktur — najpierw Rady Królewskiej, a następnie parlamentu ${ }^{15}$. Wraz z wzrostem liczby spraw oraz koniecznością powierzenia ich rozpoznawania specjalistom (których z kolei należało odciążyć od administracyjnej sfery działalności centralnego sądu przez stworzenie sprawnego aparatu administracyjnego) doszło do wyodrębnienia się Sądu Sesji jako niezależnej struktury ${ }^{16}$ na mocy ustawy z czasów panowania Jakuba V z 17 maja 1532 roku $^{17}$.

W skład Sądu wchodziło piętnastu sędziów ${ }^{18}$ (nazywanych senatorami Sesji lub Lordami Sesji): siedmiu sędziów duchownych ${ }^{19}$, siedmiu świeckich oraz Pre-

10 Stąd również wywodzi się nazwa sądu, który obradował w trakcie sesji parlamentarnej.

11 Ustawa nr $62 \mathrm{z} 1457$ roku. Zob. The Records of the Parliaments of Scotland..., http://www. rps.ac.uk/trans/1458/3/3 (dostęp: 28 kwietnia 2020).

12 Ustawa nr 63 z 1457 roku, ibidem.

13 Ustawa nr 58 z 1503 roku. Zob. The Records of the Parliaments of Scotland..., http://www. rps.ac.uk/trans/A1504/3/10 (dostęp: 28 kwietnia 2020).

14 A.J.G. Mackay, The Practice of the Court of Session: History, Constitution and Jurisdiction, t. 1, Edinburgh 1877, s. 13.

15 H.L. MacQueen, Common Law and Feudal Society in Medieval Scotland, Edinburgh 1993, s. 242.

16 Zwolnienie Lordów Sesji z innych obowiązków państwowych oraz umożliwienie im poświęcenia się rozpoznawaniu sporów sądowych podkreśla R.K. Hannay w On the Antecedents of the College of Justice, „The Book of the Old Edinburgh Club” 11, 1922, s. 107-108.

17 Ustawa nr $36 \mathrm{z} 1532$ roku. Zob. The Records of the Parliaments of Scotland..., https://www. rps.ac.uk/trans/1532/6 (dostęp: 28 kwietnia 2020).

18 Poza liczbą stałych sędziów król uprawniony był do powoływania pewnej liczby swoich przedstawicieli z grona członków rady królewskiej. Określani jako Extraordinary Lords w liczbie nie większej niż cztery osoby powiększali skład sądu, obradowali i głosowali razem ze „zwykłymi” Lordami Sesji. Ich głos liczył się tak samo, ale nie otrzymywali oni pensji oraz nie byli zaliczani do kworum. Król Jakub VI zobowiązał się do ograniczenia ich liczby do czterech, a za króla Jerzego I (panującego w latach 1714-1723) z uwagi na wprowadzoną wtedy reformę sądownictwa zaprzestano praktyki powoływania „nadliczbowych” Lordów Sesji.

19 Duży wpływ duchowieństwa na króla Jakuba V był związany z jego wieloletnią niewolą u earla Angus, z której król uwolnił się dopiero w 1528 roku, siedemnastym roku swoich rządów. 
zydent Sądu Sesji, którym był początkowo duchowny w randze prałata. Pierwszy skład Sądu został powołany w treści wspomnianej ustawy z 1532 roku $^{20}$. Powstanie szkockiego sądu centralnego zostało zatwierdzone przez papieża Klemensa VII, który zobowiązał się do współfinansowania ${ }^{21}$ działalności sądu na poziomie 10 tys. dukatów rocznie płatnych z dochodów szkockiego Kościoła ${ }^{22}$, jego następcy zaś aż do Reformacji wspierali rozwój Sądu²3.

Sąd po raz pierwszy obradował 27 maja 1532 roku, kiedy to sędziowie złożyli przysięgę względem króla oraz przedstawiciela papieża, na drugim zaś posiedzeniu, 10 czerwca 1532 roku, król ratyfikował pierwsze przepisy proceduralne, zobowiązał się do niewpływania na działanie sądu oraz przyznał uprawnienie do karania więzieniem za obrazę majestatu sądu i jego sędziów ${ }^{24}$. Kierownictwo Sądu zostało wzbogacone w 1579 roku o funkcje wiceprezydenta, który był wybierany spośród Lordów Sesji w okresie i na czas nieobecności Lorda Prezydenta ${ }^{25}$. W XVIII wieku funkcja ta uzyskała charakter stały.

Nieufny wobec szlachty opierał się w swoich rządach na duchowieństwie, a swojego dawnego nauczyciela Gavina Dunbar, arcybiskupa Glasgow, uczynił nawet kanclerzem - A.J.G. Mackay, op. cit., s. 1.

${ }^{20}$ Struktura osobowa Sądu Sesji w momencie jego stworzenia odzwierciedlała skład wcześniejszej komisji parlamentarnej oraz stopień władzy poszczególnych stanów. Jednocześnie system ten miał się załamać trzydzieści lat później na skutek szkockiej reformacji. Co jednak ciekawe, mimo zniesienia parytetu sędziów pochodzących ze stanu duchownego w dalszym ciągu chętnie powoływano spośród nich nowych Lordów Sesji do czasów ustaw wprowadzających wprost ograniczenia w tym zakresie. Zob. A.M. Godfrey, op. cit., s. 161.

${ }^{21}$ R.K. Hannay formułuje tezę, że finansowy aspekt rozwiązań przyjętych w 1532 roku jest kluczowy, ponieważ w tym roku nie tyle stworzono nową strukturę sądową, ile raczej usankcjonowano istniejące rozwiązania, zapewniając im ekonomiczne podstawy funkcjonowania. Zob. idem, On the Foundation of the College of Justice, „Scottish Historical Review” 15, 1918, s. 37. Podobnie A.A.M. Duncan, który podkreśla, że główną zaletą przyjętych rozwiązań było utrwalenie już istniejących wzorców w bardziej trwałej formie (idem, The Central Courts before 1532, [w:] Introduction to Scottish Legal History, red. G.C.H. Paton, Edinburgh 1958, s. 321-340.

22 Bulla Clementis Papae VII super summa decem milium ducatorum auri de Camera ad Collegii Jusitiae in regno Scotiae supportationem ex beneficiorum ecclesiasticorum redditibus levanda, Acts of Sederunt 1532-1553, Edinburgh 1811, s. 86 dodatku.

23 Przykładem była bulla jego następcy, Pawła III, z marca 1534 roku, w której papież uznał, że od orzeczeń duchownych Lordów Sesji nie przysługują odwołania do innych, w tym rzymskich, trybunałów duchownych. Bulla perpetuae conservatorie in forma militantis eccelse pro Collegio Justiciae serenissimi domini Scotorum Regis illustrissimi, Acts of Sederunt..., s. 87 dodatku.

24 A.J.G. Mackay, op. cit., s. 5-6.

25 Ustawa nr 93 z 1579 roku. Zob. The Records of the Parliaments of Scotland..., https:// www.rps.ac.uk/trans/1579/10/55 (dostęp: 28 kwietnia 2020). Ustawa dotyczyła przede wszystkim kwalifikacji sędziów, którymi często mianowani byli młodzi ludzie ze znakomitych rodów, pozbawieni stosownego doświadczenia i wiedzy prawniczej, brak zaś własnych majątków budził wątpliwości w zakresie ich podatności na przyjmowanie łapówek od stron oczekujących korzystnego rozstrzygnięcia. Król we wspomnianej ustawie zobowiązał się nie tylko do surowego karania występków popełnianych przez Lordów Sesji, lecz także do uważniejszego wyboru kandydatów na wakujące miejsce.

Prawo 330, 2020

(C) for this edition by CNS 
Ograniczenia w zakresie prawa do zasiadania w ławach Sądu Sesji najpierw spotkały księży parafialnych, co nastąpiło w 1584 roku ${ }^{26}$. To ograniczenie miało uniemożliwić wybór sędziów spośród przedstawicieli niższego duchowieństwa, wśród których mogły znaleźć się osoby zależne bardziej od władzy królewskiej niż będące gwarantem ochrony interesów własnego stanu. Ograniczenie to zostało rozszerzone na wszystkich przedstawicieli duchowieństwa w 1640 roku $^{27} \mathrm{i}$ od tego czasu przestał istnieć początkowy podział na Lordów duchownych (spiritual) oraz świeckich (temporal). Jednocześnie zwyczaj mianowania Lordów Sesji spośród uznanych autorytetów prawniczych w miejsce przedstawicieli znakomitych rodów sprawił, że sąd przestał być organem odzwierciedlającym układ sił w społeczeństwie stanowym, a stał się organem kształtującym ustrój prawny królestwa ${ }^{28}$.

Znaczące zmiany nastąpiły w mechanizmie wyboru Lordów Sesji. Pierwotny skład został wskazany wprawdzie w tekście ustawy, jednak o całości składu decydował król. Późniejsze nominacje odbywały się już w drodze aktu królewskiego, bez chociażby symbolicznej partycypacji parlamentu. W ostatnich dekadach XVI wieku sędziowie uzyskali jeszcze większy wpływ na skład sądu. J. Erskine wskazuje, że w 1579 roku sędziowie uzyskali prawo do wybierania Lorda Prezydenta, w 1593 roku zaś do wyboru Lordów na wakujące miejsca w ten sposób, że wybór dokonywany był z listy trzech kandydatów przedstawionych przez króla ${ }^{29}$. Uzyskana w ten sposób niezależność Sądu Sesji od pozostałych struktur władzy królestwa okazała się krótkotrwała — jeszcze w pierwszej połowie XVII wieku król przejął uprawnienie do nominowania sędziów oraz Lorda Prezydenta, którym od 1641 roku musiał się dzielić z parlamentem, uzyskując jego zgodę ${ }^{30}$. Okres restauracji dynastii Stuartów, w duchu rozwiązań wielu podobnych dylematów konstytucyjnych, oznaczał przyznanie królowi wyłącznego prawa decyzji w zakresie obsady składu Sądu Sesji ${ }^{31}$.

Początkowo jedynym wymogiem, jaki należało spełniać do objęcia stanowiska sędziego Sądu Sesji, było ukończenie 25. roku życia ${ }^{32}$. Szczegółowe wymagania w zakresie doświadczenia zawodowego kandydatów na stanowisko sędziego Sądu Sesji zostały sprecyzowane dopiero w traktacie zjednoczeniowym z 1707

26 Ustawa nr 133 z 1584 roku. Zob. The Records of the Parliaments of Scotland..., https:// www.rps.ac.uk/trans/1584/5/12 (dostęp: 28 kwietnia 2020).

27 Ustawa nr $26 \mathrm{z} 1640$ roku. Zob. The Records of the Parliaments of Scotland..., https://www. rps.ac.uk/trans/1633/6/41 (dostęp: 28 kwietnia 2020).

28 J.W. Cairns, op. cit., s. 31.

29 J. Erskine, op. cit., 1.3.7, s. 26.

30 Ustawa nr $15 \mathrm{z} 1641$ roku (uchylona w 1661 roku). Zob. The Records of the Parliaments of Scotland..., https://www.rps.ac.uk/trans/1661/1/158 (dostęp: 28 kwietnia 2020).

31 Ustawa nr 2 z 1661 roku. Zob. The Records of the Parliaments of Scotland..., https://www. rps.ac.uk/trans/1661/1/16 (dostęp: 28 kwietnia 2020).

32 J. Erskine, op. cit., 1.3.8, s. 26. W wypadku ubiegania się o stanowisko sędziego jednego z niższych sądów było to podwyższenie wymogu ukończenia 21. roku życia. 
roku ${ }^{33}$, który w artykule XIX, poświęconym zagadnieniu systemu szkockiego sądownictwa, statuował zasadę ochrony tego systemu w kształcie istniejącym przed unią, jednak przy zgodzie na wprowadzenie rozwiązań mających na celu ulepszenie wymiaru sprawiedliwości. Zgodnie ze wskazanym przepisem nie mógł zostać mianowany Lordem Sesji ten, kto nie działał jako adwokat lub wysoki urzędnik Sądu Sesji (principal clerk) ${ }^{34}$ przez pięć lat lub jako pisarz sygnetu (Writer to Signet $)^{35}$ przez okres dziesięciu lat. W przypadku pisarzy sygnetu wprowadzono wymóg skutecznego złożenia przez szkocką Radą Adwokacką (Faculty of Advocates) egzaminu z prawa rzymskiego na dwa lata przed wyborem.

Lordowie Sesji cieszyli się specjalnymi przywilejami — oprócz stosownej pensji byli zwolnieni z wszelkich podatków i danin publicznych. Jako przedstawiciele królewscy odpowiadali jedynie przed królem — oskarżenie względem sędziego Sądu Sesji musiało być przedstawione przez oskarżyciela osobiście panującemu i to król decydował zarówno o winie sędziego, jak i ewentualnej karze ${ }^{36}$.

Początkowo jurysdykcja Sądu Sesji była wąska i dotyczyła spraw cywilnych związanych z długami oraz nieruchomościami. W dalszym ciągu inne organy miały ostateczną jurysdykcje w wielu istotnych sprawach: parlament rozpoznawał sprawy dotyczące szlachectwa, Sąd Admiralicji zajmował się sprawami cywilnymi i handlowymi, dotyczącymi prawa morza, Rada Królewska zaś rozpoznawała sprawy dotyczące buntów. Ostatni z tych organów łączyła z Sądem Sesji nie tylko geneza, lecz częściowo także personel i skład osobowy, co prowadziło do rozpoznawania części spraw w mieszanym gronie ${ }^{37}$.

33 Tekst ustawy: http://rahbarnes.co.uk/union/union-of-1707/union-with-england-act-1707 (dostęp: 28 kwietnia 2020).

34 Urząd ten był najwyższym stanowiskiem administracyjnym w sądzie. Urzędnicy ci w swojej pracy posługiwali się niższymi urzędnikami nazywanymi deputy-clerks oraz assistant-clerks. $\mathrm{Na}$ tym stanowisku mogły być zatrudnione osoby, które wcześniej co najmniej przez trzy lata pracowały jako adwokaci lub pisarze sygnetu. Ich zadaniem było przygotowywanie pod kierunkiem Lordów Sesji projektów rozstrzygnięć oraz administrowanie pracą sądu. Zob. W. Bell, A Dictionary and Digest of the Law of Scotland: With Short Explanations of the Most Ordinary English Law Terms. To which is Added a Supplement, Containing an Analysis of the Court of Session Act, the Advocation and Suspension Act, the Diligence Act, and the Entail Excambion Act, Edinburgh 1838, s.v. clerk of session, s. 174-175.

35 Pisarze sygnetu należą do szczególnej grupy szkockich profesjonalnych prawników, którzy w przeszłości byli uprawnieni do nadzorowania wykorzystania królewskiego sygnetu — prywatnej pieczęci królów szkockich. Ich obowiązki były zasadniczo podobne do uprawnień współczesnych notariuszy w polskim systemie prawnym, część dokumentów wymagała bowiem potwierdzenia przez sygnet, czyli musiała uzyskać sankcję monarchy dla swojej skuteczności. Obecnie jest to niezależne od Kolegium Adwokackiego stowarzyszenie zrzeszające profesjonalnych pełnomocników prawnych. Więcej o pierwotnej roli pisarzy sygnetu zob. H.C. Black, Law Dictionary Containing Definitions of the Terms and Phrases of American and English Jurisprudence, New Jersey 1995, s.v. writer of signet, s. 1238.

36 A.J.G. Mackay, op. cit., s. 6.

37 P. McNeil, Interference with the Court of Session by the Privy Council, „Judical Review” 6, 1961, s. 254. 
Z czasem Sąd Sesji uzyskał uniwersalną jurysdykcję cywilną w sprawach, które nie podlegały specjalistycznym sądom ${ }^{38}$, a ograniczano ją jedynie w celu odciążenia centralnego sądu — sprawy mniejszej wagi, co wynikało z wartości przedmiotu sporu, musiały trafić pod rozstrzygnięcie sądu niższego stopnia, chyba że odznaczały się większym ciężarem gatunkowym lub też dotyczyły osobiście jednego z sędziów Sesji ${ }^{39}$.

Oprócz wskazanej jurysdykcji uniwersalnej, zakładającej możliwość rozpoznawania przez Sąd Sesji zasadniczo wszystkich spraw cywilnych, zaczęła się wykształcać również jurysdykcja wyłączna, która sytuowała pewne rodzaje spraw w wyłącznej kognicji sądu centralnego. Początkowo wyłączna jurysdykcja Sądu Sesji dotyczyła jedynie spraw króla oraz obcokrajowców, jednak z czasem ten katalog się powiększy ${ }^{40}$.

Znakomitą większość spraw rozpoznawanych przez Sąd Sesji stanowiły odwołania od rozstrzygnięć sądów niższego rzędu — zarówno od wyroków, jak i od zarządzeń wydawanych $\mathrm{w}$ trakcie toczącego się postępowania lub też czynności egzekucyjnych podejmowanych po jego zakończeniu ${ }^{41}$.

Niezwykle ważnym uprawnieniem było przyznanie Sądowi Sesji prawa do samodzielnego regulowania procedury sądowej obowiązującej przed nim. Na mocy ustawy z 1540 roku $^{42}$ Sąd Sesji został uprawniony do wydawania rozporządzeń procesowych, tak zwanych Acts of Sederunt. Rozporządzenia te miały za zadanie — zgodnie z tekstem ustawy z 1540 roku — regulowanie postępowania przed Sądem Sesji zgodnie z zasadami racjonalności, równości i sprawiedliwości oraz w sposób, który zapewni sprawność postępowania apelacyjnego. Uprawnienie to zostało potwierdzone w 1672 roku przy okazji utworzenia najwyższego sądu karnego w postaci Wysokiego Sądu Justycjariusza (High Court of Justiciary) ${ }^{43}$. Początkowo w jego składzie zasiadało pięciu Lordów Sesji, a dla odróżnienia działalności prawotwórczej w ramach obu sądów najwyższych stworzono nową

38 Przykładem takiej jurysdykcji były sprawy skarbowe rozpoznawane przez Sąd Szachownicy (Exchequer).

39 Ustawa nr $16 \mathrm{z} 1672$ roku. Zob. The Records of the Parliaments of Scotland..., https://www. rps.ac.uk/trans/1672/6/50 (dostęp: 28 kwietnia 2020).

40 Przykładem spraw zaliczanych do tej kategorii były sprawy dotyczące uwięzienia za długi, sprzedaży majątków nieletnich oraz bankructwa - J. Erskine, op. cit., 1.3.12, s. 28.

${ }^{41}$ C. Shand, The Practice of the Court of Session, On the Basis of the Late Mr. Darling's Work of 1833, t. 1, Edinburgh 1848, s. 20.

42 Ustawa nr 93 z 1540 roku. Zob. The Records of the Parliaments of Scotland..., https://www. rps.ac.uk/trans/1540/12/64 (dostęp: 28 kwietnia 2020). Ustawa ta formalnie ratyfikowała istnienie Sądu Sesji oraz ustanawiała zasadę prezydencji najstarszego wiekiem sędziego w przypadku nieobecności Lorda Prezydenta.

43 Był to tak zwany Courts Act z 30 sierpnia 1672 roku. Zob. The Records of the Parliaments of Scotland..., https://www.rps.ac.uk/trans/1672/6/50 (dostęp: 28 kwietnia 2020). 
kategorię rozporządzeń procesowych, które obowiązywały w zakresie spraw karnych, a które otrzymały nazwę Acts of Adjournal ${ }^{44}$.

Sędziowie Sądu Sesji nie byli związani wcześniejszymi orzeczeniami sądów niższego stopnia, a sprawy rozpoznawali na podstawie istniejącego szkockiego prawa zwyczajowego, tam zaś, gdzie nie dysponowano odpowiednimi zasadami rodzimego pochodzenia, mogli kierować się wskazówkami, jakie niosły z sobą prawo rzymskie, prawo kanoniczne oraz zasady słuszności ${ }^{45}$. Sędziowie obradowali w pełnym składzie, a dla ważności ich decyzji konieczne było osiągnięcie kworum, które początkowo ustalono na dziesięciu sędziów, a w 1587 roku obniżono do dziewięciu ${ }^{46}$.

Wśród wielu wybitnych prawników, którzy zasiadali w ławach Sądu Sesji między XVIa XVIII wiekiem jeden z nich ma szczególne znaczenie zarówno dla samego Sądu, jak i dla kształtu szkockiego porządku prawnego. Mowa tutaj o Jamesie Darlymple, pierwszym wicehrabim Stair, nazywanym szkockim Grocjuszem $^{47}$, który wysławił się nie tylko autorstwem pierwszego ${ }^{48} \mathrm{z}$ dzieł instytucjonalnych ${ }^{49}$, lecz także wieloletnią pracą w Sądzie Sesji. Był jednym z sędziów odtworzonego w wyniku restauracji Stuartów w 1661 roku Sądu, następnie wiceprezydentem, a od 1671 roku do kryzysu przysięgowego w 1681 roku był Lordem Prezydentem Sądu Sesji. Przebywając na wygnaniu w Niderlandach, związał się ze środowiskiem stadhoudera Niderlandów i późniejszego króla Anglii Wilhelma Orańskiego, co przyczyniło się do przywrócenia go na stanowisko Lorda Prezy-

44 H.C. Black, op. cit., s.v. adjournal, s. 35.

45 J.W. Cairns, The Civil law tradition in Scottish legal thought, [w:] The Civilian Tradition and Scots Law, red. D. Carey Miller, R. Zimmermann, Edinburgh 1997, s. 200-203.

46 Ustawa nr $44 \mathrm{z} 1587$ roku. Zob. The Records of the Parliaments of Scotland..., https://www. rps.ac.uk/trans/1587/7/37 (dostęp: 28 kwietnia 2020).

47 K. Reid, R. Zimmermann, Mixed legal systems and the place of Scots law, [w:] A History of Private Law in Scotland, t. 1, red. K. Reid, R. Zimmermann, Oxford 2000, s. 6.

48 Wydanych w 1681 roku Institutions of the Law of Scotland.

49 Dzieła instytucjonalne to traktaty prawnicze, które w ocenie przedstawicieli szkockiej judykatury uzyskały status subsydiarnego źródła prawa. Ich wyjątkowy charakter wynikał z wypełnienia istotnych luk w szkockim prawie prywatnym oraz stosunkowo dużej żywotności dzieł szkocki system prawny bowiem ani w XIX wieku, ani później nie doczekał się kompleksowej kodyfikacji prawa prywatnego. Znaczenie dzieł opierało się na wadze, jaką wyrażonym w nich opiniom autorów przypisywali ówcześni oraz późniejsi prawnicy — teoretycy i praktycy, stosując je jako przedmiot wykładu czy uzasadnienie wyroków. Dzieła instytucjonalne powstały w określonym momencie historycznym jako odpowiedź na potrzebę wykształcenia się odrębnego i nowoczesnego systemu szkockiego prawa prywatnego. Historia w ten sposób zatoczyła więc koło — dzieła instytucjonalne, które sprowadziły do roli pomników prawa źródła prawa z okresu średniowiecznego, same w toku XX oraz XXI wieku uzyskały taki status w wyniku swojej dezaktualizacji przez utrwalenie się precedensowego charakteru szkockiego sądownictw. Więcej w J.W. Cairns, Institutional writings in Scotland reconsidered, [w:] New Perspectives in Scottish Legal History, red. A. Kiralfy, H.L. MacQueen, London 1984; K. Luig, The Institutes of National Law in the seventeenth and eighteenth centuries, „Juridical Review” 17, 1972. 
denta Sądu Sesji, które sprawował od 1689 roku do swojej śmierci w 1695 roku $^{50}$. Dzieło stworzone przez Staira stanowiło istotną barierę chroniącą rodzimy system prawny przed jego ewentualną anglicyzacją, opracowane zaś orzecznictwo Sądu Sesji z lat 1661-1681 było pierwszym wydanym drukiem zbiorem orzecznictwa ${ }^{51}$, który ułatwiał zapoznawanie się przez sądy niższego stopnia z dorobkiem jurydycznym sądu najwyższej instancji.

Rola Sądu Sesji została utrzymana i umocniona przez władców krótkiego okresu między Chwalebną Rewolucją a powstaniem Wielkiej Brytanii — za panowania Wilhelma Orańskiego i Marii Stuart szkocki parlament przyjął w 1693 roku wiele ustaw dotyczących procedury sądowej, odnoszących się również do Sądu Sesji, a proces zjednoczeniowy przeprowadzony w trakcie panowania królowej Anny zagwarantował, co zostało już wspomniane, przetrwanie Sądu Sesji w niezmienionym kształcie ${ }^{52}$.

Istnienie Sądu Sesji oraz unifikująca rola jego orzecznictwa były niezwykle istotnym mechanizmem ochrony rodzimego charakteru szkockiego systemu prawnego, narażonego zarówno na dobrowolną, jak i przymusową anglicyzację w dobie unii realnej. Pojawienie się w strukturze organów Królestwa Szkocji sądu centralnego $\mathrm{z}$ jednej strony wpisywało się w istniejący w Europie trend wyodrębniania się z rady królewskiej wyspecjalizowanych organów odpowiedzialnych za poszczególne prerogatywy panującego, z drugiej zaś w przypadku Szkocji było odebraniem wykonywania tej prerogatywy z rąk przedstawicieli stanów na rzecz posiadających wysokie kompetencje jurydyczne profesjonalnych sędziów. Niezależność Sądu Sesji, przejawiająca się najsilniej w prawie do samostanowienia zasad proceduralnych, stanowiła istotną gwarancję roli i wagi sądu w nowym otoczeniu prawnym, w którym sąd znalazł się w momencie powstania Zjednoczonego Królestwa Wielkiej Brytanii.

\section{Bibliografia}

\section{Ustawy szkockiego parlamentu}

Nr 65 z 1425 roku, http://www.rps.ac.uk/trans/1426/25.

$\mathrm{Nr} 62$ z 1457 roku, http://www.rps.ac.uk/trans/1458/3/3.

$\mathrm{Nr} 63$ z 1457 roku, http://www.rps.ac.uk/trans/1458/3/3.

Nr 58 z 1503 roku, http://www.rps.ac.uk/trans/A1504/3/10.

50 Więcej o życiorysie wicehrabiego Staira — zarówno w zakresie jego działalności piśmienniczej, jak i politycznej - J.G. Mackay, Memoir of Sir James Dalrymple, First Viscount of Stair, Edinburgh 1873; J.L. Duncan, The life and times of Viscount Stair, „Juridical Review” 1934; oraz J. Thomson, The first Viscount of Stair, „Juridical Review” 1924.

51 Stair, Decisions of the Lords of Session, Edinburgh 1683 (t. 1) oraz 1687 (t. 2).

52 A.J.G. Mackay, The Practice of the Court of Session: History..., s. 26. 
Nr 36 z 1532 roku, https://www.rps.ac.uk/trans/1532/6.

$\mathrm{Nr} 93$ z 1540 roku, https://www.rps.ac.uk/trans/1540/12/64.

$\mathrm{Nr} 93$ z 1579 roku, https://www.rps.ac.uk/trans/1579/10/55.

$\mathrm{Nr} 133$ z 1584 roku, https://www.rps.ac.uk/trans/1584/5/12.

$\mathrm{Nr} 44$ z 1587 roku, https://www.rps.ac.uk/trans/1587/7/37.

Nr 15 z 1641 roku, https://www.rps.ac.uk/trans/1661/1/158.

$\mathrm{Nr} 26$ z 1640 roku, https://www.rps.ac.uk/trans/1633/6/41.

$\mathrm{Nr} 2$ z $1661 \mathrm{roku}$, https://www.rps.ac.uk/trans/1661/1/16.

$\mathrm{Nr} 16$ z 1672 roku, https://www.rps.ac.uk/trans/1672/6/50.

\section{Literatura}

Acts of Sederunt 1532-1553, Edinburgh 1811.

Bell W., A Dictionary and Digest of the Law of Scotland: With Short Explanations of the Most Ordinary English Law Terms. To which is Added a Supplement, Containing an Analysis of the Court of Session Act, the Advocation and Suspension Act, the Diligence Act, and the Entail Excambion Act, Edinburgh 1838.

Black H.C., Law Dictionary Containing Definitions of the Terms and Phrases of American and English Jurisprudence, wyd. 11, New Jersey 1995.

Cairns J.W., The civil law tradition in Scottish legal thought, [w:] The Civilian Tradition and Scots Law, red. D. Carey Miller, R. Zimmermann, Edinburgh 1997.

Cairns J.W., Revisiting the Foundation of the College of Justice, [w:] Miscellany V, red. H.L. MacQueen, Edinburgh 2006.

Duncan A.A.M., The Central Courts before 1532, [w:] Introduction to Scottish Legal History, red. G.C.H. Paton, Edinburgh 1958.

Duncan J.L., The Life and Times of Viscount Stair, „Juridical Review” 1934.

Erskine J., The Principles of the Law of Scotland, wyd. 6, Edinburgh 1783.

Godfrey A.M., Civil Justice in Renaissance Scotland: The Origins of a Central Court, Boston 2009.

Guenée B., States and Rulers in Later Medieval Europe, Oxford 1985.

Hannay R.K, The College of Justice, Edinburgh 1991.

Hannay R.K., On the Antecedents of the College of Justice, „The Book of the Old Edinburgh Club” $11,1922$.

Hannay R.K., On the Foundation of the College of Justice, „Scottish Historical Review” 15, 1918.

Lorimer J.C., History of the Court of Session, ,Journal of Jurisprudence” 16, 1872, nr 185.

Lovat-Fraser J.A., Differences between English and Scots law, „Law Quaterly Review” 10, 1894.

Mackay A.J.G., The Practice of the Court of Session: History, Constitution and Jurisdiction, Edinburgh 1877.

Mackay A.J.G., Memoir of Sir James Dalrymple, First Viscount of Stair, Edinburgh 1873.

MacQueen H.L., Common Law and Feudal Society in Medieval Scotland, Edinburgh 1993.

McNeil P., Interference with the Court of Session by the Privy Council, „Judical Review” 6, 1961.

The Records of the Parliaments of Scotland to 1707, red. K.M. Brown, St. Andrews 2007-2020.

Reid K., Zimmermann R., Mixed legal systems and the place of Scots law, [w:] A History of Private Law in Scotland, t. 1, red. K. Reid, R. Zimmermann, Oxford 2000.

Shand C., The Practice of the Court of Session, On the Basis of the Late Mr. Darling's Work of 1833 , t. 1, Edinburgh 1848.

Thomson J., The first Viscount of Stair, „Juridical Review” 1924.

Prawo 330, 2020

(C) for this edition by CNS 


\section{Some remarks on the origins and role of the Court of Session in the Kingdom of Scotland (1532-1707)}

\section{Summary}

The purpose of this article is to illustrate the origins and evolution of the central court of the Kingdom of Scotland from its inception in 1532 until the end of the Kingdom as an independent entity of international law following its establishment in 1707 of the United Kingdom of Great Britain. The analysis of the structure of the court is based on the laws of the old Scottish Parliament, and the main thesis of the study is the evolutionary nature of the provisions constituting the Court of Sessions which, on the one hand, were a continuation of the King's previous jurisdictional powers and, on the other hand, were part of a wider trend towards separation of central courts from the royal councils in European monarchies.

Keywords: Court of Session, civil procedure, Scots law, mixed jurisdictions

\section{Einige Bemerkungen zur Genese und Bedeutung von Court of Session im Königreich Schottland (1532-1707)}

\section{Zusammenfassung}

Gegenstand dieses Beitrages ist die Darstellung der Genese und der Evolution des zentralen Gerichtes im Königreich Schottland in der Zeit von seiner Entstehung im Jahre 1532 bis zum Ende des Königreiches als ein unabhängiges Subjekt des internationalen Rechtes, infolge der Entstehung im Jahre 1707 des Vereinigten Königreiches von Großbritannien. Grundlage der Analyse der Struktur des Gerichtes stellen die Gesetze des ehemaligen schottischen Parlamentes und die wichtigste These der Bearbeitung stellt der evolutionäre Charakter der Lösungen dar, die zur Gründung von Court of Session geführt haben. Diese stellten einerseits die Fortführung der früheren Befugnisse des Königs im Bereich Jurisdiktion, andererseits aber waren sie in den europäischen Monarchien ein Teil der umfassenderen Bewegung der Aussonderung der Zentralgerichte aus der Institution der königlichen Räte.

Schlüsselwörter: schottisches Oberstes Gericht (Sessionsgericht), Zivilverfahren, schottisches Recht, hybride (gemischte) Rechtssysteme 